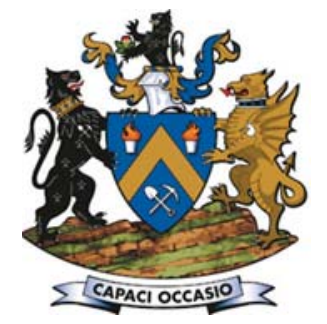

\title{
A methodology for laboratory testing of rockbolts used in underground mines under dynamic loading conditions
}

\author{
by A. Pytlik*, S. Prusek*, and W. Masny*
}

\section{Synopsis}

Underground mining is subject to various natural hazards such as seismic events, rockbursts, fire, and gas (methane). In general, an increase in the extraction depth causes an increase in the likelihood of these hazards, especially seismic activity and rockbursts. Dynamic phenomena such as rockbursts and tremors have been recorded on six continents: Europe (Poland, Russia, Czech Republic, Germany, and Slovenia), Asia (India, and China), North and South America (USA, Canada, and Chile), Africa (South Africa), and Australia. To select appropriate mine working supports for such dynamic phenomena, the performance characteristics of such support types must be determined under both static and dynamic load conditions.

This article presents information regarding the application of rockbolts in Polish underground hard-coal mines. Dynamic phenomena occurring in the mines from 2004-2013 are also characterized. A methodology developed at the Central Mining Institute (GIG) for the laboratory testing of rockbolts is presented. In this methodology, the bolts are loaded by the direct impact of a free-moving mass (up to $20000 \mathrm{~kg}$ ) at speeds of up to $1.2 \mathrm{~m} / \mathrm{s}$. The facilities at GIG used to test the support under static and dynamic load conditions are characterized, and the results of laboratory tests on yielding bolts with a nominal capacity of $420 \mathrm{kN}$ are presented. These types of bolts are commonly used for reinforcing steel arches and the surrounding rock mass in Polish coal mines. The results of the laboratory testing of yielding bolts are discussed..

Keywords

underground hard-coal mining, rockbolts, dynamic load, laboratory testing methodology, yielding bolts.
2013; Nierobisz, 2013; Mark, 2014; Masny and Prusek, 2015). One of the main goals of the research has been to develop methods, criteria, and guidelines for the selection of an optimal and safe support for mine workings located in areas of rock bumps or tremors. Example of such studies include the Canadian Rockburst Support Handbook (Kaiser, McCreath, and Tannant, 1996), or the principles presented in the literature (Li, 2010; Cai, 2013). The general principle in mine workings subjected to the risk of a dynamic load is to utilize a yielding support (yielding bolts) or rebar bolts of various lengths. This support can be connected to other types of support such as mesh or shotcrete. All parts of a support system must absorb the dynamic energy released during the tremor or rockburst as well as minimize the deformation (convergence) of the working. A number of construction solutions have been applied to meet the principles of a yielding support in regions of burst-prone ground. There are numerous examples of bolts capable of transferring dynamic loads, including Cone Bolts, Durabar, D-Bolts, Roofex, Garford, Yield-Lok, and CRLD (constant resistancelarge deformation bolts) (Ortlepp, Bornman, and Erasmus, 2001; Neugebauer, 2008; Li, 2010, Campoli, Oldsen, and Wu, 2012; He and Sousa, 2014). However, according to Kaiser et al. (1996), due to practical and economic limitations it is not practical to provide an energy capacity greater than $50 \mathrm{~kJ} / \mathrm{m}^{2}$ for ground support. This level was termed the 'maximum practical support limit' (MPSL), and once reached, it is considered impractical to prevent damage to mine openings by increasing the amount or changing the type of ground support. Other strategic measures must then be taken to reduce the rockburst damage potential and workers' exposure to hazards (Heal, 2010).

* Central Mining Institute, Katowice, Poland.

(c) The Southern African Institute of Mining and Metallurgy, 2016. ISSN 2225-6253. Paper received Jul. 2015; revised paper received Jan. 2016. 


\section{A methodology for laboratory testing of rockbolts used in underground mines}

To optimize the support selection for mine workings subject to dynamic loads, laboratory and site tests were conducted. Laboratory studies on the impact of dynamic events on a support or their individual components have been performed at many test facilities. These facilities are located, for example, in Dortmund (Germany), Opava (Czech Republic), Carletonville (Savuka mine, Republic of South Africa), Greater Sudbury (Creighton mine, Canada), Noranda Inc. Technology Center (Canada), Walenstadt (Switzerland), and Kalgoorlie (Western Australia School of Mines, Australia) (Gaudreau, Aubertin, and Simon, 2004; Human and Ortlepp, 2004; Sosnica, 2008; Player, Villaescusa, and Thompson, 2008; Roth et al., 2014). A comprehensive review of test rigs was provided by Hadjigeorgiou and Potvin (2008). Laboratory methods for testing dynamically loaded supports are described by Player, Villaescusa, and Thompson (2008). The authors have identified the following laboratory test methods for simulating dynamic loads:

$>$ Direct impact of mass on an element

> Impact of the structure/element on a fixed element

- Impact of the structure/element on a moveable element, e.g. military collision testing of loaded railway wagons

- Impact of a mass on a load transfer mechanism or energy dissipation element.

A number of underground tests of supports subject to dynamic loads have been conducted in various mines, including coal, copper, zinc, and iron ore mines. From the perspective of test methodology, these tests can be divided into two main groups. In the first group, the measurements were performed during naturally occurring dynamic phenomena. In the second group, the measurements of dynamic events were conducted using explosives to simulate dynamic phenomena (Kidybin'ski, 1986; Stjern and Myrvang, 1998; Hagan et al., 2001; Tannant, Kaiser, and McDowell, 1992; Masny, 2006; Heal and Potvin, 2007; Hadjigeorgiou and Potvin, 2008; Nierobisz, 2012).

Seismic activity experienced by Polish underground hardcoal mines from 2004-2013 is characterized in this article. The current status regarding the scope of the application of rockbolting in Polish coal mines is also described, along with the methodology of laboratory dynamic tests of the bolts developed at the Central Mining Institute, Katowice, Poland. The results of selected tests of the yielding bolts are presented.

\section{General characteristics of hard coal mining industry in Poland}

In 2013 there were 30 underground coal mines, producing 76.5 million tons of hard coal, in operation in Poland. The longwall method is used for the extraction of multiple seams. In 2013, 107 longwall panels were retreated with single entries (101 faces with natural roof caving into the gob and six with hydraulic backfilling). The average depth of the cover was $713 \mathrm{~m}$; however, increasingly more collieries are exploiting coal deposits located at depths of approximately $1000 \mathrm{~m}$. The significant extraction depth and the stress concentration caused by the interaction of edges or remnant pillars in the mined-out seams induces seismic activity and rockburst hazards in the mines (Stec, 2014). Information regarding seismic activity, rockbursts, numbers of accidents, and the lengths of damaged workings is shown in Figure 1 and Table I (Patyńska, 2014).

Table I shows the production of coal in Poland from 2003-2013, including the seams mined in areas subject to rockburst hazards, the number of rockbursts, the number of accidents, and the length of damaged workings (Patyniska, 2014).

The data presented in Figure 1 and Table I shows that hard coal production decreased from 102.5 Mt to $76.5 \mathrm{Mt}$ from 2003 to 2013. During this period, 39\% to $50 \%$ of coal production originated from seams located in rockburst areas. The number of rockbursts per year ranged from 1 to 5 , resulting in 125 minor to severe accidents and 11 fatalities. Between $360 \mathrm{~m}$ and $3200 \mathrm{~m}$ of mine workings were destroyed or damaged as a result of rockbursts. Examples of damaged workings after rockbursts are shown in Figure 2.

According to Polish mining law, yielding-type support is required in coal seams extracted in seismic areas subject to rockburst hazards. Therefore, in most cases, yielding steel arches support the workings. The arches are a primary support installed in the working face during the development by roadheaders. The distance between the arches ranges from $0.5 \mathrm{~m}$ to $1.0 \mathrm{~m}$. The steel arches have a V-shaped cross-sectional profile and a mass of between $25 \mathrm{~kg} / \mathrm{m}$ and $36 \mathrm{~kg} / \mathrm{m}$. Under demanding conditions, the steel arches are reinforced using various types of support, mostly steel horseheads, wooden and steel props, or cribs. In recent years bolts have been installed as reinforcement for steel arches and the surrounding rock mass (Prusek and Masny, 2013; Prusek, Masny, and Turek, 2014). Figure 3 shows the length of the developed workings in 2012 and the proportions of different types of supports used. An example of combined support (steel arches, fully grouted rebars, and yielding bolts) is presented in Figure 4.

The basic characteristics of bolts employed in Polish hard coal mines are listed in Table II.

\section{Test facilities at GIG and bolt testing methodology under dynamic load conditions}

Research on different types of supports used in underground coal mines has been conducted at GIG for many years. The tests are usually conducted by exerting static or dynamic loads on the support. The technical specifications of the dynamic test facility enable the examination of components with dimensions of up to $5 \times 2 \times 6 \mathrm{~m}$ (height $\times$ width $\times$ length) through the direct impact of a 1000-20 $000 \mathrm{~kg}$ freely moving mass. The maximum impact energy is $500 \mathrm{~kJ}$, and the initial

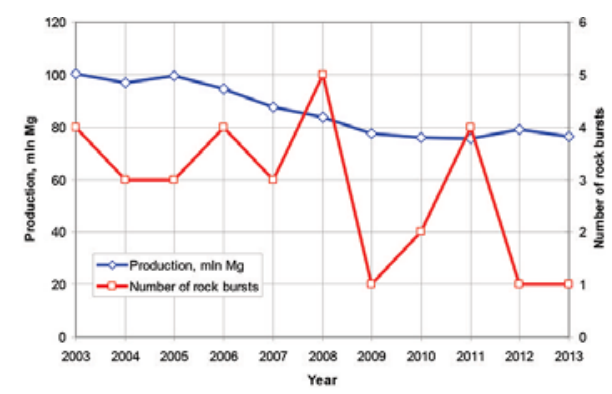

Figure 1-Hard coal production and the number of rockbursts in Polish coal mines from 2003-2013 (Patyńska, 2014) 


\section{A methodology for laboratory testing of rockbolts used in underground mines}

\begin{tabular}{|c|c|c|c|c|c|c|c|c|c|}
\hline \multicolumn{10}{|c|}{ Table I } \\
\hline \multicolumn{10}{|c|}{$\begin{array}{l}\text { Total hard coal production, production from seams located in rockburst areas, the accident rate, the number of } \\
\text { rockbursts, the number of accidents, and the length of the mine workings damaged due to rockbursts from } \\
2003-2013 \text { (Patyńska, 2014) }\end{array}$} \\
\hline \multirow[t]{2}{*}{ Year } & $\begin{array}{c}\text { Total } \\
\text { production }\end{array}$ & \multicolumn{2}{|c|}{$\begin{array}{l}\text { Extraction from seams } \\
\text { located in rockburst areas }\end{array}$} & \multirow{2}{*}{$\begin{array}{l}\text { Accident ratio } \\
\text { (accidents/ } \\
\text { extraction) }\end{array}$} & \multirow[t]{2}{*}{$\begin{array}{c}\text { No. of } \\
\text { rockbursts }\end{array}$} & \multicolumn{2}{|c|}{$\begin{array}{l}\text { Rockburst } \\
\text { accidents }\end{array}$} & \multicolumn{2}{|c|}{$\begin{array}{l}\text { Consequence in } \\
\text { mine workings }\end{array}$} \\
\hline & \multicolumn{2}{|c|}{ Mt } & $\%$ to general & & & Fatal & Other & $\begin{array}{c}\text { Destroyed } \\
\text { after rock fall }(\mathrm{m})\end{array}$ & $\begin{array}{l}\text { Damaged, } \\
(\mathrm{m})\end{array}$ \\
\hline 2003 & 100.40 & 41.8 & 40.9 & 0.18 & 4 & 2 & 16 & 110 & 145 \\
\hline 2004 & 96.99 & 39.2 & 39.4 & 0.11 & 3 & 0 & 11 & 0 & 358 \\
\hline 2005 & 99.50 & $41.0^{(1)}$ & $41.2^{(1)}$ & 0.13 & 3 & 1 & 12 & 0 & 270 \\
\hline 2006 & 94.50 & 42.15 & 44.6 & 0.25 & 4 & 4 & 20 & 0 & $>510$ \\
\hline 2007 & 87.40 & $44.6^{(1)}$ & $49.43^{(1)}$ & 0.11 & 3 & 0 & 10 & 0 & 530 \\
\hline 2008 & 83.60 & $41.9(2)$ & 50.12 & 0.31 & 5 & 0 & 26 & 0 & 710 \\
\hline 2009 & 77.5 & $34.3(3)$ & 43.8 & 0.06 & 1 & 0 & 5 & 0 & 101 \\
\hline 2010 & 76.1 & $35.8(4)$ & 47.04 & 0.18 & 2 & 2 & 12 & 30 & 87 \\
\hline 2011 & 75.50 & $34.2^{(5)}$ & 45.36 & 0.08 & 4 & 1 & 6 & 0 & 168 \\
\hline 2012 & 79.20 & 37.60 & 47.47 & 0.04 & 1 & 1 & 2 & $170^{(1)}$ & $210^{(1)}$ \\
\hline 2013 & 76.47 & 36.90 & 48.25 & 0.07 & 1 & 0 & 5 & 50 & 113 \\
\hline
\end{tabular}

(1)Approximate data

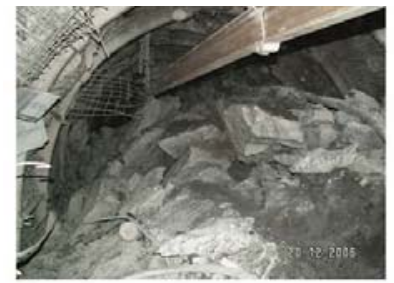

a)

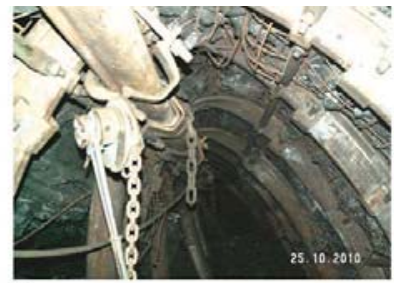

b)

Figure 2-Damaged mine workings after rockburts. (a) Strong floor heave in the working, (b) deformation of steel arches

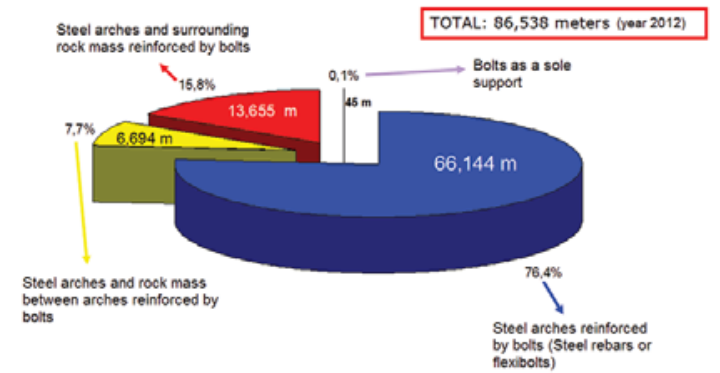

Figure 3-Length of developed mine workings in 2012 and the percentage use of different types of support (Turek, Prusek, and Masny, 2015)

load setting of the hydraulic cylinders can be up to $2 \mathrm{MN}$. Figure $5 \mathrm{a}$ shows the facility for the tests of yielding steel arches under static load conditions. The test facility for the lining support is shown in Figure 5b (Pytlik, 2013b, 2013c, 2014).

\section{Bolt testing under dynamic load conditions}

One issue that influenced research on methodologies for bolts subjected to dynamic loads was the lack of relevant Polish standards. Initially, this methodology (Pytlik, 2005) was
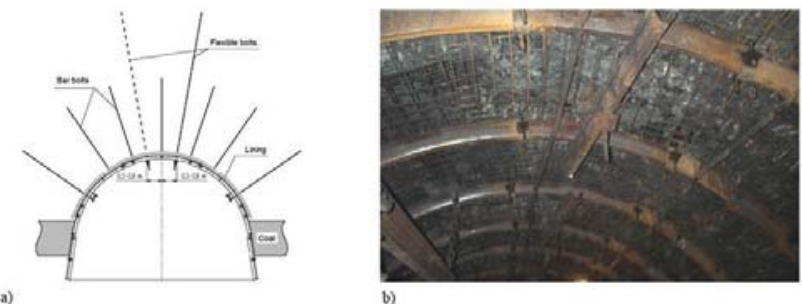

Figure 4-Examples of combined support of workings used in Polish hard-coal mines - steel arches and surrounding rock mass reinforced by fully grouted rebars and yielding bolts (Karlikowski and Kozek, 2013; Prusek, 2008)

Table II

Basic characteristics of the bolts used in Polish coal mines (Turek, Prusek, and Masny. 2015)

\begin{tabular}{|l|c|c|c|c|c|}
\hline \multirow{2}{*}{ Bolt type } & \multicolumn{2}{|c|}{$\begin{array}{c}\text { Diameter of bolt } \\
\text { (mm) }\end{array}$} & $\begin{array}{c}\text { Length of bolt } \\
\text { (m) }\end{array}$ & $\begin{array}{c}\text { Load-bearing } \\
\text { capacity } \\
\text { (kN) }\end{array}$ \\
\cline { 2 - 5 } & From & To & From & To & \\
\hline Yielding bolts & 20 & 30 & 3.0 & 12.0 & $280-430$ \\
Rebar bolts (rigid) & 16 & 40 & 1.0 & 3.1 & $120-300$ \\
Injection bolts & 20 & 43 & 1.3 & 11.0 & $50-430$ \\
Cuttable bolts & 25 & 41 & 3.0 & 6.0 & $30-120$ \\
Expansion shell bolts & 20 & 40 & 0.8 & 1.5 & 120 \\
Cable bolts & 18 & 18 & 6.0 & 6.0 & 300 \\
\hline
\end{tabular}

designed to determine the dynamic resistance of yielding bolts under so-called 'explosive' rockburst conditions associated with the rapid disintegration of coal. This methodology assumed that a bolt should dissipate the impact energy without its elements being destroyed. The kinetic energy of the load is $25.0 \mathrm{~kJ}$. A traverse with a mass of 2000 $\mathrm{kg}$ was used to exert the static load on a bolt prior to the dynamic impact. The test consisted of an impact by a $4000 \mathrm{~kg}$ free-falling mass. The parameters were selected in accordance 


\section{A methodology for laboratory testing of rockbolts used in underground mines}

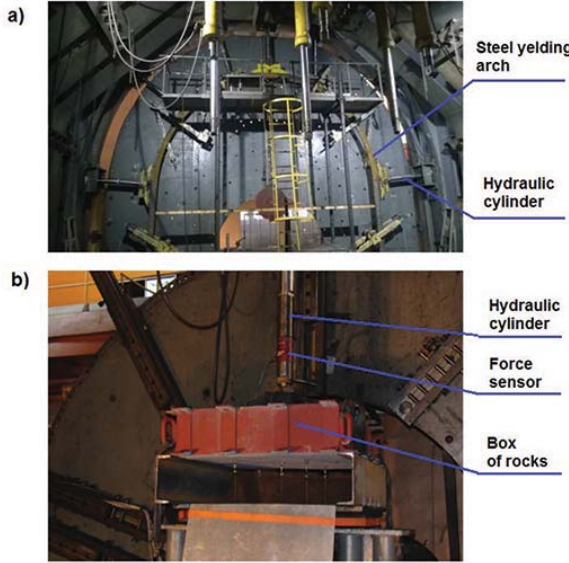

Figure 5-The test facilities at the Central Mining Institute (GIG). (a) Facility for testing steel arches at full scale, (b) facility for testing lining supports (e.g. shotcrete and TSL)

with the assumptions made for cases of 'explosive' rockbursts. This resulted in an impact speed of approximately $3 \mathrm{~m} / \mathrm{s}$ (corresponding to the impact of the free-falling mass from a height of approximately $0.97 \mathrm{~m}$ ). The high impact velocity used in the tests does not correspond to the rockburst model involving large masses of rock according to peak particle velocity (PPV) studies (Kidybiński, 1999).

The current research methodology (Pytlik, 2015) allows the dynamic load of a large mass (from 10000 to $20000 \mathrm{~kg}$ ) to be applied to the bolt. The essence of the study consists of statically preloading a bolt by a traverse with a mass $m_{2}$. The main dynamic load is exerted by the impact of a free-falling mass $m_{1}$ from a height $h$. During the test, the loading speed $v_{u}$ depends on the height $h$. The impact speed $v_{u}$ is calculated under the assumption of a plastic collision of the masses $m_{1}$ and $m_{2}$. The speed $v_{o}$ of the free-falling mass from the height $h$ at the traverse at the moment of impact is calculated from

$$
v_{o}=\sqrt{2 g h}
$$

where

$h$ - height, $\mathrm{m}$

$g$ - acceleration due to gravity, $\mathrm{m} / \mathrm{s}^{2}$.

The speed $v_{o}$ is not the speed of the dynamic load in the test of the support component. After the plastic collision, the system consists of combined masses $m_{1}$ and $m_{2}$. To calculate the speed $v_{u}$ of the joined masses $m_{1}$ and $m_{2}$, the principle of conservation of momentum is used:

$$
m_{1} \cdot v_{o}=\left(m_{1}+m_{2}\right) v_{u}
$$

from which we obtain

$$
v_{u}=v_{o} \frac{m_{1}}{m_{1}+m_{2}}
$$

According to Equation [3], a portion of the kinetic energy of the free-falling mass $m_{1}$ is lost to set the traverse (with mass $m_{2}$ ) in motion. The combined system of masses $m_{1}$ and $m_{2}$ has a lower velocity. The speed $v_{u}$ is taken as the initial speed of the load. This value is substituted into the kinetic energy calculation formula of the combined masses $m_{1}$ and $m_{2}$ :

$$
E_{k}=\frac{1}{2}\left(m_{1}+m_{2}\right) v_{u}^{2}
$$

After substituting Equations [1] and [3] into Equation [4], we obtain

$$
E_{k}=\frac{m_{1}^{2}}{\left(m_{1}+m_{2}\right)} \mathrm{g} \cdot \mathrm{h}
$$

where

$m_{1}$ - mass of free-falling mass, $\mathrm{kg}$

$m_{2}$ - mass of traverse, $\mathrm{kg}$

$h$ - fall height of free-falling mass, $m$

$g$ - acceleration due to gravity, $\mathrm{m} / \mathrm{s}^{2}$.

The average friction force $F_{t}$ from the start of the bolt protrusion from the cylinder until the end of the feed of the bolt is calculated as follows:

$$
F_{t}=\frac{\int_{t 1}^{t 2} F_{d} d t}{\Delta t}
$$

where

$t_{1}$ - feed start time of the bolt from the cylinder, $\mathrm{s}$

$t_{2}$ - feed end time of the bolt from the cylinder, $\mathrm{s}$

Using the test facility, it is possible to examine both the mechanical components of the bolt (Figure 6a) as well as the bonded bolt in the steel cylinder (Figure 6b). The bolt is placed in a cylinder filled with concrete with a specified compressive strength.

During the test, the dynamic values of the breaking force and deformation of the bolts are measured. These parameters determine the stability of the support and are essential to the development of support projects for mine workings.

The development of the test methodology was guided by the analysis of seismic observations in Polish hard-coal mines (Dubiński and Mutke, 1996; Mutke, 2007) conducted in the region of the so-called near-field wave. This research showed that $90 \%$ of rock bumps occurred in the area where the PPV reached 0.05 to $1.0 \mathrm{~m} / \mathrm{s}$. Other data from the literature (Kidybiński, 2009) revealed that for PPV $\geq 0.4 \mathrm{~m} / \mathrm{s}$, there is a high risk of loss of stability of the mine workings. This implies the possibility of support destruction. This PPV value was also confirmed by Mutke (2012). In general, the $\mathrm{PPV}$ value is considered as a measure of the dynamic effect of the rockburst on the support (Potvin, Wesseloo, and Heal, 2010).

The speed of the free-falling mass in the GIG test facility, $v_{u}$, is not the same as the PPV on the surface of the mine workings. The methodology assumes that such correlation exists and applies only to the first impulse of the load and not to the wave motion. This is because in addition to the wave motion, there is another rock mass movement, which is a

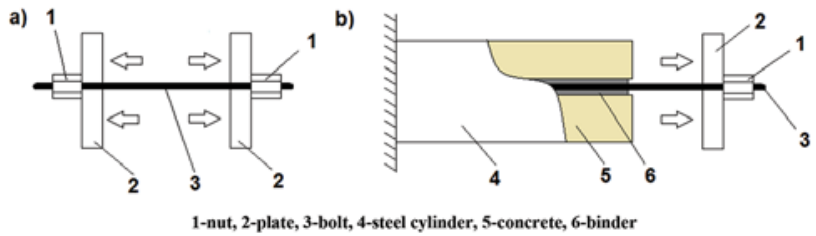

Figure 6-Schematic of the test method for bolts: (a) testing mechanical components, (b) pull-out test. 1-nut, 2-plate, 3-bolt, 4-steel cylinder, 5-concrete, 6-binder 


\section{A methodology for laboratory testing of rockbolts used in underground mines}

common cause of the destruction of mine workings (Drzewiecki, 2002). This movement is associated with the motion of large volumes of rock mass initiated by the creation or propagation of discontinuities. The direction of this movement is consistent with the area with the most degrees of freedom.

The new methodology identifies five categories of bolts based on dynamic resistance. The classification is based on the initial velocity, $v_{u}$, of rock masses moving into the mine workings, as shown in Table III, where $h$ is the fall height of the free-falling mass:

Using the developed methodology, the performance characteristics of bolts are determined under a dynamic impulse load. During the tests, the bearing capacity and yielding of the bolts are determined. These parameters are important for the design of rockbolts intended for use in areas subject to rockburst hazards.

Both the mechanical components of bolts (Pytlik, 2005, 2013a, 2015) - i.e., the wires, washers, and nuts - as well as bolts bonded in a steel cylinder (Pytlik, 2015) can be tested in the facility. The cylinders are filled with concrete or a cement-mineral binder with a predetermined ultimate compressive strength. Based on Polish standards (PN-G15092: 1999), the uniaxial compressive strength (UCS) should be greater than $50 \mathrm{MPa}$. The test facility also allows the adhesiveness of the resin or cement binder to the bolt wires to be checked. When testing bolts bonded to a steel cylinder, the length and dimensions can be adapted to the requirements of Polish standards (PN-G-15092: 1999). For bolts mounted sectionally in a cylinder, the standards require the test length to be at least $210 \mathrm{~mm}$. For bolts secured along the entire length of the cylinder, a length of $1000 \mathrm{~mm}$ is assumed. In practice, it is often assumed that the bonding length of the bolts should not be less than $0.6 \mathrm{~m}$. The initial tension of the bolts should not be less than $30.0 \mathrm{kN}$.

The relationship of the bolt dynamic resistance $F_{d}$ as a function of load time $t$ (at the desired impact speed $v_{u}$ ) characterizes the performance characteristics of a dynamically loaded bolt. The maximum force of dynamic resistance $F_{\text {dmax }}$ is determined during the test. This value depends on the kinetic energy of the free-falling mass. The maximum impact speed $v_{u}$ at which any element of the bolt is not damaged (the continuity of the material is not interrupted, and the bolt retains its functionality) is the basis for classifying these bolts into one of five categories of bolt impact resistance: W1-W5.

The mass of the free-falling mass in the test facility is taken as $24000 \mathrm{~kg}$, assuming that the average bulk density of rocks moving into the mine workings is $2400 \mathrm{~kg} / \mathrm{m}^{3}$, and

Table III

Impact resistance categories for rockbolts (Pytlik, 2015)

\begin{tabular}{|l|c|c|}
\hline Category & $\boldsymbol{v}_{\boldsymbol{u}}(\mathbf{m} / \mathbf{s})$ & $\mathbf{h}(\mathbf{c m})$ \\
\hline W1 & 0.4 & 1.3 \\
W2 & 0.6 & 3.0 \\
W3 & 0.8 & 5.0 \\
W4 & 1.0 & 8.0 \\
W5 & 1.2 & 12.0 \\
\hline
\end{tabular}

the volume is $10 \mathrm{~m}^{3}$.

A full tension test of a bolt using this methodology is performed in two stages (Pytlik, 2015). In the first stage, the bolt's mechanical components are examined according to the scheme shown in Figure 7.

The examination of the bolt consists of the following:

(a) Preparing the bolt to be tested by securing it on both sides with nuts and washers

(b) Exerting a static load on the bolt (which simulates pre-tension of the bolt) by a traverse with instrumentation with a total mass $m_{2}=4000 \mathrm{~kg}$ (traverse mass $m_{t}=3300 \mathrm{~kg}$, instrumentation weight $m_{o}=700 \mathrm{~kg}$ ). In the next step, the load is increased by an additional mass $m_{1}=20000 \mathrm{~kg}$ over 5 seconds. A positive test result is obtained if the bolts transfer the given load without damage (the continuity of the material is not interrupted)

(c) Unloading the bolt by raising the free-falling mass $\left(m_{1}\right)$ to a predetermined height $h$ (in the range from approximately 1 to $12 \mathrm{~cm}$ ) corresponding to the given load speed $v_{u}$ of 0.4 to $1.2 \mathrm{~m} / \mathrm{s}$

(d) Releasing the free-falling mass (with $m_{1}=20000$ $\mathrm{kg}$ ) into free fall from a height $h$ above the traverse $\left(m_{2}=4000 \mathrm{~kg}\right)$.

The test result in the first step is considered to be positive if any element of the bolt is not damaged (the continuity of the material is not interrupted, and the bolt retains it functionality).

During the bolt test, the instantaneous value of the dynamic resistance force $F_{d}$ is recorded. From the obtained data, a maximum value $F_{\text {dmax }}$ is determined. Before and after the test, the length of the bolt $L$ is measured. This enables the elongation $\Delta L$ of a tested bolt to be determined.

Bolts that pass the first stage of research are tested in step 2. In this stage, a bolt is bonded to the steel cylinder. The scheme of the test for this step is shown in Figure 8.

The examination of the bolt in the second stage consists of the following:

(a) Installation of the bolt (Figure 8) into the steel cylinder at approximately $400 \mathrm{~mm}$. TSM 70 adhesive with a nominal UCS of $70 \mathrm{MPa}$ is used as the binder. After the installation, the bolt is left for 14 days. The binder achieves the required strength of UCS $=$ $50 \mathrm{MPa}$ over this time

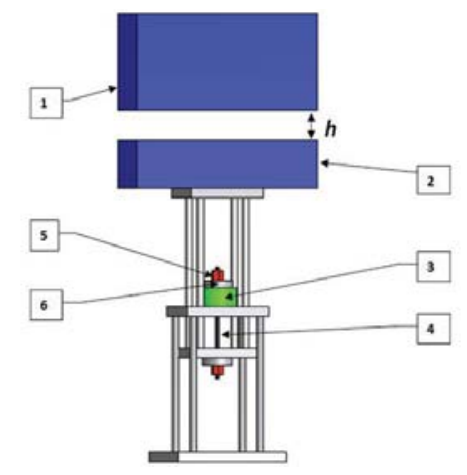

Figure 7-The test facility prepared for the examination of mechanical components under dynamic load with a free-falling mass: (1) free-falling mass $\left(m_{1}\right),(2)$ traverse (with mass $\left.m_{2}\right)$, (3) force sensor, (4) bolt rod, (5) bolt nut, (6) bolt washers 


\section{A methodology for laboratory testing of rockbolts used in underground mines}

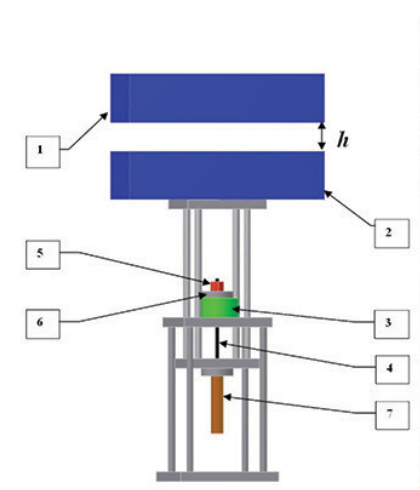

a

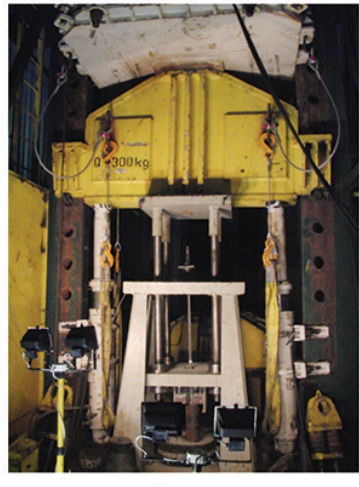

b

Figure 8-The test facility prepared for phase 2 testing applying a dynamic load to the bolt in a steel cylinder: (a) - scheme; (b) photograph showing (1) the free-falling mass $\left(m_{1}\right),(2)$ traverse (with mass $m_{2}$ ), (3) force sensor, (4) bolt rod, (5) bolt nut, (6) bolt washer, (7) steel cylinder

(b) A static load is exerted on the bolt (which simulates pre-tensioning of the bolt) via a traverse with instrumentation having a total mass $m_{2}=4000 \mathrm{~kg}$ (traverse mass $m_{t}=3300 \mathrm{~kg}$, instrumentation weight $m_{0}=700 \mathrm{~kg}$ ). In the next step, the load is increased using an additional mass $m_{1}=20000 \mathrm{~kg}$ over 5 seconds

(c) The bolt is unloaded by raising the free-falling mass $\left(m_{1}\right)$ to a predetermined height $(h$, in the range from approximately 1 to $12 \mathrm{~cm}$ ) corresponding to the given load speed $v_{u}$ of 0.4 to $1.2 \mathrm{~m} / \mathrm{s}$

(d) Releasing the free-falling mass $\left(m_{1}=20000 \mathrm{~kg}\right)$ into free fall from height $h$ onto the traverse $\left(m_{2}=\right.$ $4000 \mathrm{~kg}$ ).

The test result in the second step is considered to be positive if the bolt transfers the given load without suffering damage (the continuity of the material is uninterrupted), and the bolt does not protrude from the steel cylinder by more than $80 \%$ of its length.

The maximum values of the impact speed vu obtained during the test in stages 1 and 2 form the basis for the classification of the bolt into one of the impact resistance categories. These categories are shown in Table III (W1-W5). When classifying a bolt, a lower impact speed from the test results of stage 1 and 2 is selected.

During the tensile impact load test of a bolt bonded to the steel cylinder, the momentary dynamic resistance force $F_{d}$ of the bolt is recorded. During this test, the maximum value $F_{\text {dmax }}$ of the momentary dynamic resistance force $F_{d}$ of the bolt is determined. Before and after the test, the length $L$ of the bolt and the bolt geometry are measured to determine its elongation $\Delta L$ or the length of the extension from the steel cylinder $\Delta L_{w}$ (Figure 9).

All measurement data was recorded with a minimum test frequency of $9600 \mathrm{~Hz}$. For the force measurement, strain gauges and HBM measuring amplifiers were used. Each bolt was tested according to the presented methods. If the condition of the bolts allowed, tests on the destroyed bolts (or shearing that occurred at the wire-binder or binder-concrete interface) were continued to determine their post-critical load capacity.

\section{Results and analysis of the yielding bolt tests conducted under dynamic load conditions}

In this section, selected results of the yielding bolt tests conducted at the GIG facility under dynamic load conditions using the methodology described in the previous section are presented. The study objects were yielding bolts with a nominal load-bearing capacity of $420 \mathrm{kN}$. A schematic of the bolt is shown in Figure 10.

The bolts were composed of a bundle of eight wires with a diameter of $7 \mathrm{~mm}$, seven of which were located peripherally to one wire at the centre. The bolts also incorporated a cylinder liner and a nut with an $M 42 \times 2$ threading. The outer diameter of the yielding bolt was approximately $23 \mathrm{~mm}$, and the length approximately $1.5 \mathrm{~m}$.

Load-deflection curves of force $F$ to elongation $L$ of three bolts are shown in Figure 11. Undamaged wires transferred a load of 430 to $442 \mathrm{kN}$.

In a subsequent step, a test was conducted on the mechanical components of the yielding bolts under dynamic loading.

In the first stage of the examination, the bolts were found to meet the requirements of the W3 impact resistance category. The maximum dynamic resistance force $F_{\text {dmax }}$ was approximately $420 \mathrm{kN}$. An example chart of the dynamic resistance force is illustrated in Figure 12. The abovementioned bolt was not damaged and maintained its functionality during the test at an impact speed of $v_{u}=0.8 \mathrm{~m} / \mathrm{s}$. After the test, it was found that only the bolt wires had protruded from the steel cylinder by approximately $80 \mathrm{~mm}$. Fading vibrations of forces are visible in the graph. Their envelope is similar to a power curve.

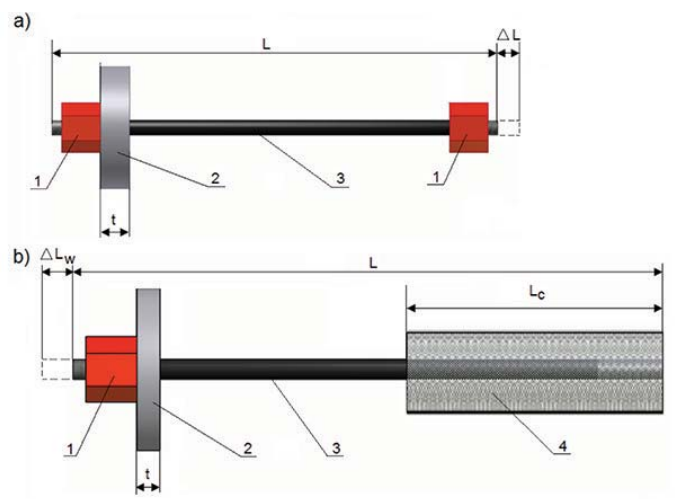

Figure 9-Scheme of the measurements performed during the test: (1) nut, (2) plate, (3) bolt, (4) steel cylinder, $L=$ length of the bolt, $\Delta L=$ =elongation of the bolt, $\Delta L_{w}=$ extension from the steel cylinder, $L_{c}=$ length of the steel cylinder

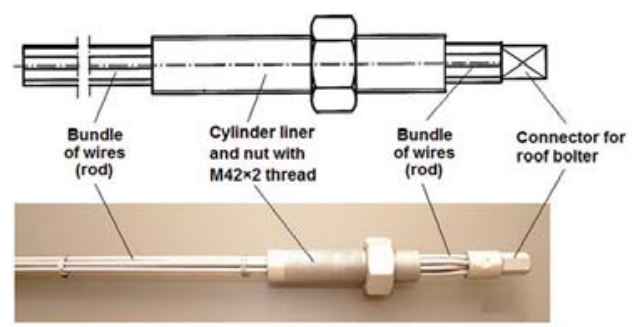

Figure 10-Mechanical construction scheme and photograph of yielding bolt (www.interram.pl) 


\section{A methodology for laboratory testing of rockbolts used in underground mines}
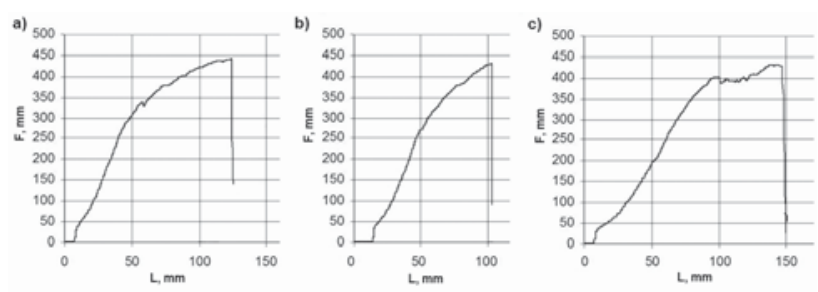

Figure 11-Load-deflection curves for three tensile tests on mechanical elements of the bolts

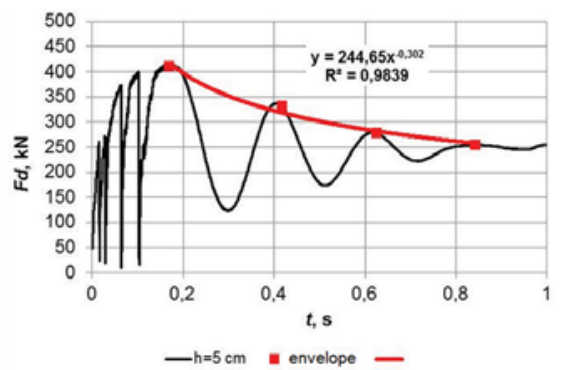

Figure 12-Dynamic resistance force $\left(F_{d}\right)$ vs time $(t)$ for the yielding bolt at an impact speed $v_{u}=0.8 \mathrm{~m} / \mathrm{s}(h=0.05 \mathrm{~m})$ - the bolt was not destroyed

Figure 13 shows an example chart of the dynamic resistance force of the bolt, which was destroyed by breaking of the wires in a wedge clamp. The clamp was located inside the cylinder liner.

In the second stage of the dynamic tests, the yielding bolts were bonded to the steel cylinder with a TSM-70K mineral cement-type binder. The characteristics of TSM-70K were determined in accordance with PN-EN 196-1: 2006. The UCS strengths after 1, 3, 7, and 28 days are shown in Figure 14. To bind the bolts inside the steel cylinder, a hole with a diameter of $32 \mathrm{~mm}$ was drilled.

As indicated by the graph demonstrating the strength of the TSM-70K binder, the parameters considerably exceed the requirements of the Polish standard (PN-G-15091: 1998). The Polish standards specify that the minimum UCS strength of cement and other mineral binders be $5 \mathrm{MPa}$ after 3 days following mixing of the components.

An additional test (not included in the Polish standards governing the requirements) relevant to bolts used in mining (PN-G-15091: 1998, PN-G-15091: 1999) was also performed. The test consisted of pulling a bolt with a length of approximately $400 \mathrm{~mm}$ out of the steel cylinder with a quasi-static load (extension rate of the bolt, $v$, of approximately $20 \mathrm{~mm} / \mathrm{min}$ ). The test was performed 3 days after binding in the cylinder. The force $F$ pulling the bolt from the steel cylinder as a function of bolt extension length $L$ and as a function of time $t$ is shown in Figure 15.

During this test, the mechanical components of the bolts were not damaged; however, the connection was sheared at the wire-bonder interface. This study confirmed that the anchor had a relatively high static load capacity of up to $350 \mathrm{kN}$ after three days of being bonded. The greatest bearing capacity loss occurred when a bolt protruded from a cylinder a distance of approximately $220 \mathrm{~mm}$.

The test results for the yielding bolts under dynamic loading (14 days after bonding) are shown in the graphs in Figures 16 and 18 . The bolts were bonded to a steel cylinder

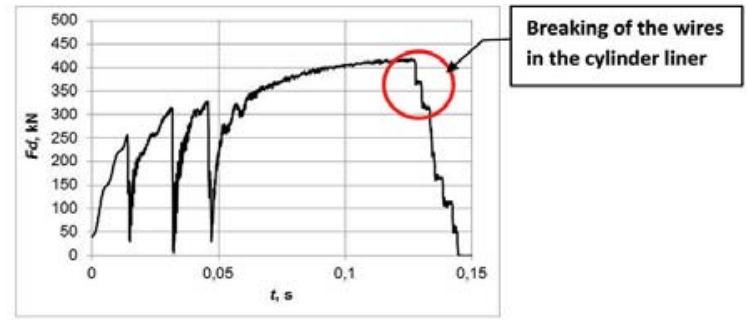

Figure 13-Dynamic resistance force $\left(F_{d}\right) v s$ time $(t)$ for the yielding bolt at an impact speed $v_{u}=0.9 \mathrm{~m} / \mathrm{s}(h=0.07 \mathrm{~m})$ - the bolt was destroyed

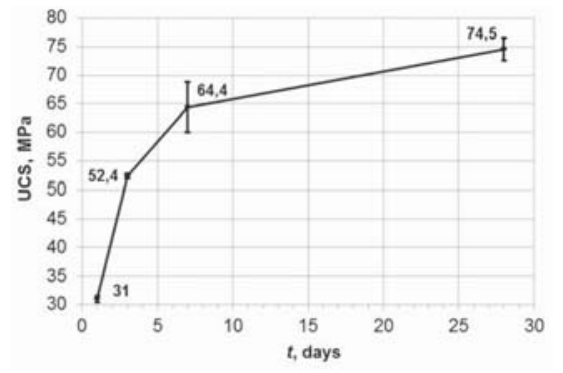

Figure 14-Uniaxial compressive strength of TSM-70K binder
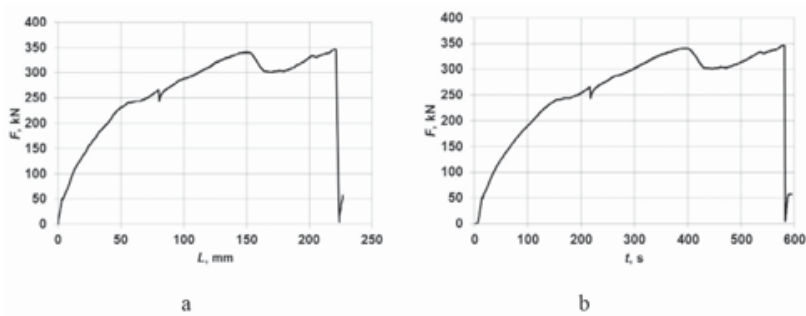

Figure 15-Graphs of force $(F)$ used to pull the yielding bolt from the cylinder under static load (three days after being bonded within a cylinder): (a) as a function of bolt extension length (L); (b) as a function of time $(t)$

with a length of approximately $400 \mathrm{~mm}$. The tests were performed with an impact speed $v_{u}$ of 0.6 to $0.8 \mathrm{~m} / \mathrm{s}$. The results of these tests were negative and prevented the classification of the bolts into the W3 category (they do not meet the lower W2 category). The test results 21 days after bonding are shown in Figures 19 and 20. A summary of test results and calculations is shown in Table IV.

Based on the analysis of the graphs presented in Figures 16 and 18, it can be concluded that the wires protruded from the cylinder in each of the laboratory tests (in tests of bolts 14 days after bonding). This was caused by shearing at the wire-binder interface. The loss of adhesion between the wires and binder in the steel cylinder previously occurred at a force of $F_{d}=110 \mathrm{kN}$. As this process proceeded, the rod advanced in pulses from the hole in the cylinder. The test was continued until the bearing capacity of the bolt was totally lost. The rod, washer, and nut remained intact after the test.

To test the effect of the binding time of a mineral binder, various studies of bolts ( 21 days after the bolts were mounted to the steel cylinder) were performed. As shown in Figure 19, the bolt transferred the dynamic load without being damaged. This load was exerted by the free-falling mass released from a height of $h=0.4 \mathrm{~m}$. This exceeds the requirements for bolts in the impact resistance category $\mathrm{W} 2$. 


\section{A methodology for laboratory testing of rockbolts used in underground mines}

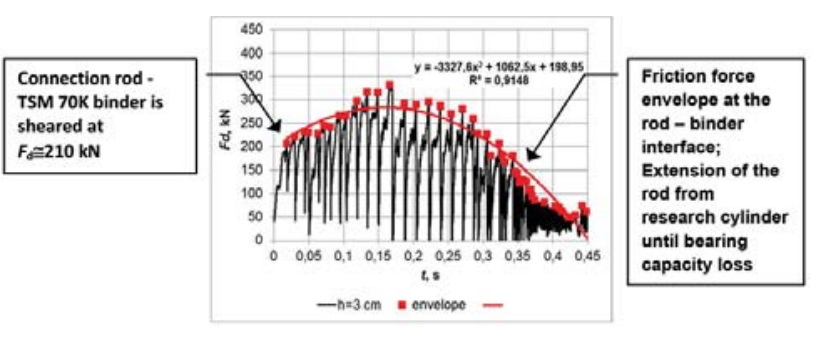

Figure 16-Graph of dynamic resistance force $\left(F_{d}\right)$ vs time $(t)$ for the yielding bolt at an impact speed $v_{u}$ of $0.6 \mathrm{~m} / \mathrm{s}(h=0.03 \mathrm{~m}, 14$ days after bonding) - test no. 1

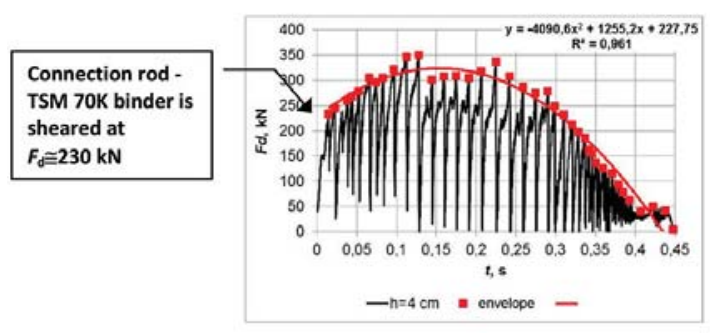

Figure 17-Graph of dynamic resistance force $\left(F_{d}\right)$ vs time $(t)$ for yielding bolt at an impact speed $v_{u}$ of $0.7 \mathrm{~m} / \mathrm{s}(h=0.04 \mathrm{~m}, 14$ days after bonding) test no. 2

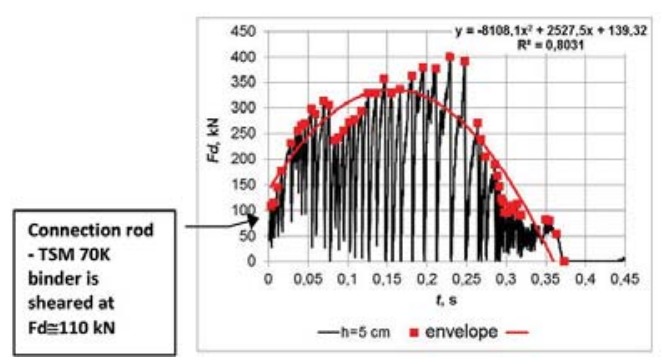

Figure 18-Graph of dynamic resistance force $\left(F_{d}\right)$ vs time $(t)$ for yielding bolt at an impact speed $v_{u}$ of $0.8 \mathrm{~m} / \mathrm{s}(h=0.05 \mathrm{~m}, 14$ days after bonding) test no. 3
Although the rods protruded from the cylinder (over a length of $27 \mathrm{~mm}$ ), the bolt did not protrude from the cylinder. In comparison with studies after 14 days, the wire-binder interface transferred a load of $F_{d}=420.6 \mathrm{kN}$ (an increase of $83 \%$ compared to sample no. 2 , as shown in Figure $15 ; F_{d}=$ $230 \mathrm{kN}$ ) during the bolt test 14 days after mounting in the cylinder. The first two maximum values of the force shown in the graph (Figure 19) are related to the momentary sliding of the rod at the interface with the binder. The bolt remained able to dissipate an impact energy of $E_{k}=6.7 \mathrm{~kJ}$. After stabilization in the hole, damping of the bolt vibrations occurred. The envelope is shown in the chart.

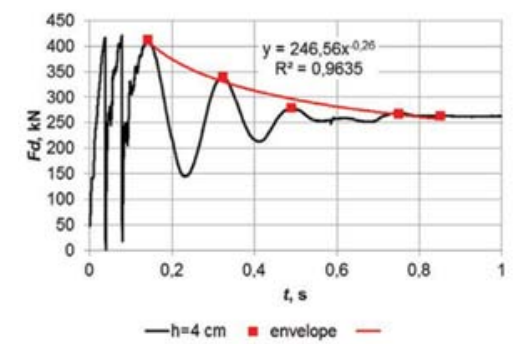

Figure 19-Graph of dynamic resistance force $\left(F_{d}\right)$ vs time $(t)$ for yielding bolt at an impact speed $v_{u}$ of $0.7 \mathrm{~m} / \mathrm{s}(h=0.04 \mathrm{~m}, 21$ days after bonding) - test no. 4

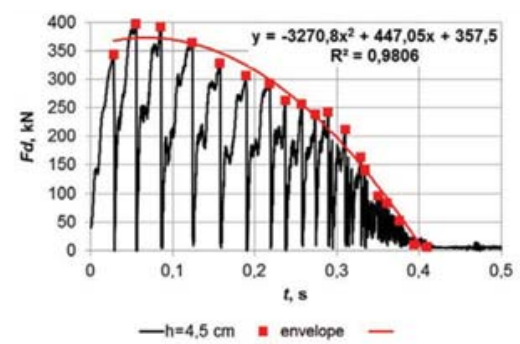

Figure 20-Graph of dynamic resistance force $\left(F_{d}\right)$ vs time $(t)$ for yielding bolt at an impact speed $v_{u}$ of $0.7 \mathrm{~m} / \mathrm{s}(h=0.045 \mathrm{~m}, 21$ days after bonding) - test no. 5

\begin{tabular}{|c|c|c|c|c|c|c|c|}
\hline \multicolumn{8}{|c|}{$\begin{array}{l}\text { Table IV } \\
\text { Yielding bolt test results in stage 2- in steel cylinder }\end{array}$} \\
\hline $\begin{array}{l}\text { Test } \\
\text { no. }\end{array}$ & $\begin{array}{l}\text { Number of days after bonding } \\
\text { the bolt to a cylinder }\end{array}$ & $h(\mathrm{~m})$ & $F_{d \max }(\mathrm{kN})$ & $F_{t}(\mathrm{kN})$ & $v_{u}(\mathrm{~m} / \mathrm{s})$ & $E_{k}(\mathrm{~kJ})$ & $\begin{array}{l}\text { Visual inspection after the } \\
\text { experiment }\end{array}$ \\
\hline 1 & 14 & 0.03 & 332.5 & 148.7 & 0.64 & 5.1 & \multirow{3}{*}{$\begin{array}{l}\text { No damage to the mechanical parts of the bolt. } \\
\text { Wires protruded fully from the cylinder. } \\
\text { Shearing at wire-binder interface. }\end{array}$} \\
\hline 2 & 14 & 0.04 & 349.8 & 162.9 & 0.74 & 6.7 & \\
\hline 3 & 14 & 0.05 & 401.2 & 169.1 & 0.83 & 8.4 & \\
\hline 4 & 21 & 0.04 & 420.6 & 302.3 & 0.74 & 6.7 & $\begin{array}{l}\text { No damage to the mechanical parts of the bolt. } \\
\text { Wires protruded from the cylinder to a length of } 27 \mathrm{~mm} \text {. }\end{array}$ \\
\hline 5 & 21 & 0.045 & 397.9 & 174.6 & 0.81 & 7.6 & $\begin{array}{l}\text { No damage to the mechanical parts of the bolt. } \\
\text { Wires protruded fully from the cylinder } \\
\text { Shearing at wire-binder interface }\end{array}$ \\
\hline
\end{tabular}

$h$ - the fall height of the impact mass, $m$

$F_{d \max }$ - the maximum dynamic resistance force, $\mathrm{kN}$

$F_{t}$ - the average frisction force, $\mathrm{kN}$

$v_{u}$-the impact speed, $\mathrm{m} / \mathrm{s}$

$E_{k}$ - the kinetic energy, $\mathrm{kJ}$ 


\section{A methodology for laboratory testing of rockbolts used in underground mines}

During the tests (classifying the bolt in the W3 category; $v_{u}=0.8 \mathrm{~m} / \mathrm{s}$ ), the bolts subject to an impact speed of $0.7 \mathrm{~m} / \mathrm{s}$ protruded from the steel cylinder. The bolt did not transfer the load (without being damaged), as indicated in the graph in Figure 20.

Figures 21 and 22 present examples of the yielding bolts after the tests.

Under dynamic loads resulting from an impact at speeds $v_{u}$ in the range of 0.6 to $0.8 \mathrm{~m} / \mathrm{s}$, none of the mechanical components of the yielding bolt were damaged, indicating that the weakest component was the wire-binder interface. Thus, the length of the bonding in the hole must be increased, ensuring full use of the bearing capacity of the bolt. A significant increase in the load-bearing capacity of the bolt can also be obtained by extending the setting time, which was confirmed by the performed tests ( 21 days after bonding).

The study also shows that, despite the shearing of the connection between the rod and the binder, the bolt did not completely lose its bearing capacity and continued to function on the principle of frictional contact in the hole until complete extension of the rod from the hole. During this frictional contact, the resistance was observed to vary in pulses and decreased to zero. Despite the relatively short cylinders (with a length of approximately $400 \mathrm{~mm}$ ) in the tests, maximum values of the dynamic resistance forces $F_{\text {dmax }}$ in the range of 330.0 to $420.6 \mathrm{kN}$ were obtained. This is important for the bolts' post-critical performance, i.e., after shearing at the wire-binder interface.

Analysis of the yielding bolt performance during its extension out of the steel cylinder (after shearing at the rodbinder interface) demonstrated that the friction force between the rod and the wall of the cylinder hole was nonlinear. This was assumed by Gaudreau, Aubertin, and Simon (2004). The shape of the frictional force envelope is similar to a power function. In Figures 15 and 19, the protrusion process of the rod from the cylinders consists of impulse forces. These forces correspond to the rods slipping until the test is halted or until the rods extend totally out of the cylinder. The charts also show the equations of the envelopes of the friction force $F_{t}$. The differences in performance of the yielding bolt after 14 and 21 days can be observed.

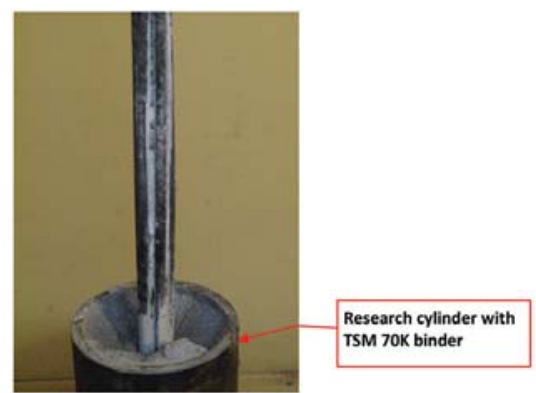

Figure 21-Bolt rod protruding from the cylinder after the test

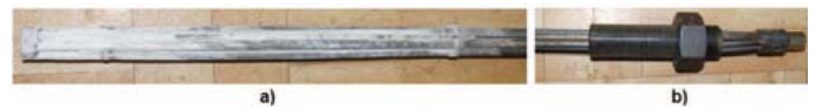

Figure 22-Yielding bolt after the test (without damage) as a threaded cylinder liner and nut

\section{Summary}

To select appropriate mine working supports for conditions that may include exposure to dynamic phenomena, the performance of such supports must be determined under dynamic conditions. One of the commonly used methods of support assessment under dynamic loading is laboratory testing using a free-falling mass impacting a test object. This article described a methodology for the laboratory testing of rockbolts developed by and employed at the GIG for the study of bolt behaviour under dynamic load conditions. The parameters of the laboratory tests were defined by considering the estimated speed of the rock mass during rock bumps and tremors in Polish coal mines. In the GIG test facilities, it is possible to dynamically load the tested bolts using the momentum of a large freely moving mass (20 000 $\mathrm{kg}$ ) applied to bolts at speeds of up to $1.2 \mathrm{~m} / \mathrm{s}$. In Polish underground coal mines, the primary support of workings, erected during development, is steel arches. Under difficult geo-mining conditions, the steel arch and surrounding rock mass are reinforced using bolts. During the exploitation of coal seams, severe rockbursts and tremors occur each year. The occurrence of these phenomena means that, prior to application of different supports in mine workings, it is necessary to assess their bearing capacity under dynamic load. Such assessment is possible with the methodology described in this paper, as confirmed by test results of yielding bolts.

Given past experience, bolts with a minimum category of impact resistance of W3 are recommended for use in Polish underground coal mines.

\section{Acknowledgements}

This article presents a brief summary of work conducted by the Central Mining Institute under the project Innovative Technologies and Concepts for the Intelligent Deep Mine of the Future. The project is implemented under the Seventh Framework Programme of the European Union.

\section{References}

BRÄUNER, G. 1991. Rockmass pressure and rockburst. Verlag Glückauf, Essen [in German].

CAI, M. 2013. Principles of rock support in burst-prone ground. Tunnelling and Underground Space Technology, vol. 36. pp. 46-56.

CAMPoli, A., OldSEN J., and Wu, R. 2012. Yielding bolt support for rockburst prone workings. Aachen International Mining Symposium - Rockbolting in Mining and Rock Mechanics in Mining. RWTH Aachen. pp. 205-211.

Driad-Lebeau, L., Lahaie, F., Al Heib, M., Josien, J.P., Pascal Bigarre, P., and NoIREL, J.F. 2005. Seismic and geotechnical investigation following a rockburst in a complex French mining district. International Journal of Coal Geology, vol. 64. pp. 66-78.

DRZEWIECKI, J. 2002. The collapse of the mining workings due to movements of rocks. Proceedings of the International Scientific-Technical Symposium 'Rockburst 2002'. The State of Research and Prevention. Central Mining Institute, Katowice, Poland [in Polish].

DuвiŃsкi, J. and Kоnорко, W. 2000. Rockburst. Evaluation. Prediction. Fighting. Central Mining Institute, Katowice, Poland [in Polish].

DuBiŃsKI, J. and MuTKE, G. 1996. Characteristics of mining tremors within the near-wave field zone. PAGEOPH, vol. 147, no. 2. pp. 249-261.

DuRRHEIM, R. and RIEMER, K. 2012. History of endeavours to mitigate the rockburst risk in South African mines. Proceedings of the International Mining History Congress, Johannesburg, South Africa, 17-20 April. Royal Society of Chemistry. pp. 1-17.

Gaudreau, D., Aubertin, M., and Simon R. 2004. Performance of tendon support systems submitted to dynamic loading. Proceedings of the Fifth International Symposium on Ground Support in Mining and Civil Engineering Construction, Perth, Australia. 28-30 September 2004 Villaescusa, E. and Potvin, Y. (eds.). Balkema, Lisse. pp. 299-312. 


\section{A methodology for laboratory testing of rockbolts used in underground mines}

Hadigeorgiou, J. and Potvin, Y. 2008. Overview of dynamic testing of ground support. Proceedings of Deep Mining 07, the 4th International Seminar on Deep and High Stress Mining. Potvin, Y. (ed.). Australian Centre for Geomechanics, Perth, Australia. pp. 349-371.

Hagan, T.O., Milev, A.M., Spottiswoode, S.M., Hildyard, M.W., Grodner, M., Rorke, A.J., Finnie, G.J., Reddy, N., Haile, A.T., Le Bron, K.R., and Grave, D.M. 2001. Simulated rockburst experiment - an overview. Journal of the South African Institute of Mining and Metallurgy, vol. 101, no. 5. pp. 217-222.

HE, M. and SousA, L. 2014. Experiments on rockburst and its control. Proceedings of AusRock 2014: the Third Australasian Ground Control in Mining Conference, Sydney, Australia, 5-6 November. Australasian Institute of Mining and Metallurgy, Melbourne. pp. 19-31.

HEAL, D. 2010. Observations and analysis of incidences of rockburst damage in underground mines. PhD thesis, School of Civil and Resource Engineering, University of Western Australia.

HEAL, D. and Potvin, Y. 2007. In situ dynamic testing of ground support using simulated rockbursts. Proceedings of the 4th International Seminar on Deep and High Stress Mining. Potvin, Y. (ed.). Australian Centre for Geomechanics, Perth, Australia. pp. 373-394.

Holub, K., RuŠAJOvÁ, J., and HolečKo, J. 2011. Particle velocity generated by rockburst during exploitation of the longwall and its impact on the workings. International Journal of Rock Mechanics \& Mining Sciences, vol. 48. pp. 942-949.

Human, J.L. and ORTLEPP, W.D. 2004. Large scale testing of stope support systems under "realistic" rockburst conditions. Proceedings of the 2nd International Seminar on Deep and High Stress Mining, February 2004 Symposium Series S37. Southern African Institute of Mining and Metallurgy, Johannesburg. pp. 107-121.

KAISER, P. and CAI, M. 2012. Design of rock support system under rockburst condition. Journal of Rock Mechanics and Geotechnical Engineering, vol. 4, no. 3. pp. 215-217.

KaISER, P.K., McCREATH, D., and TANnAnt, D. 1996. Canadian Rockburst Support Handbook. Geomechanics Research Centre, Laurentian University.

KarLIKowsKI, S. and Kоzeк, В. 2013. The problems of reconstruction and maintenance of roadways in 'Bogdanka' hard coal mine in light of the many years of experience Mining News, vol. 64, no. 11. pp. 633-643 [in Polish].

KIDYBIŃsKI, A. 1986. Design criteria for roadway support to resist dynamic loads. International Journal of Mining and Geological Engineering, vol. 4. pp. 91-109.

KIDYBIŃSKI, A. 1999. Criteria of damage or destruction of roadway and chamber workings as a result of tremors. Occupational Safety and Environmental Protection in Mining, no./ 5/99. [in Polish]. State Mining Authority.

KIDYBINSKK, A. 2003. Rockburst hazard in the world mining industry recognition and prevention methods. Research report no. 1/2003. Central Mining Institute, Katowice. pp. 5-35 [in Polish].

KIDYBIŃsKI, A. 2009. Stability of rockmass and support under the static and dynamic load conditions, Central Mining Institute, Katowice, Poland [in Polish].

LI, C. 2010. Principles of rock bolting in high stress rock masses. Prace Naukowe GIG, No. 2/1/2010. pp. 133-143.

LI, T., CAI, M.F., and CAI, M. 2007. A review of mining-induced seismicity in China. International Journal of Rock Mechanics \& Mining Sciences, vol. 44. pp. 1149-1171.

MARK, C. 2014. Coal bursts in the deep longwall mines of the United States. Proceedings of AusRock 2014: the Third Australasian Ground Control in Mining Conference, Sydney, Australia, 5-6 November. Australasian Institute of Mining and Metallurgy, Melbourne. pp. 33-39.

MASNY, W. 2006. Practical application of the sensors for measuring of static and dynamic loadings. XXIX Winter School of Rock Mechanics and Geoengineering, Krynica, Poland, 12-17 March. pp. 237-245. [in Polish].

MAsny, W. and PruseK, S. 2015. Analysis of damage to underground workings and their supports caused by dynamic phenomena. Journal of Mining Sciences, vol. 51, no. 1. pp. 63-72

MUTKE, G. 2007. Characteristic of near field ground motion resulting from mining tremors to assessing of rockburst hazard.Thesis-monograph no. 872 , Scientific Series of Central Mining Institute Katowice, Poland [in Polish].

MUTKE, G. 2012. Methods for assessing the impact of dynamic phenomena on underground workings. The Safety of Mixed Support under the Dynamic Load Conditions. Turek, M. (ed.). Central Mining Institute, Katowice, Poland. pp. 18-70 [in Polish].

Neugebauer, E. 2008. Ready for roofex. A new way to tackle safety in underground operations. Mining and Construction, no. 3. pp. 12-13.

NiERoBisz, A. 2012. The role of support in maintenance of underground workings in the rockburst hazard conditions. Thesis-monograph no. 887. Central Mining Institute, Katowice, Poland [in Polish].

Polish Standard PN-G-15091:1998 - Rockbolts - Requirements. Polski Komitet Normalizacy (PKN), Warsaw [in Polish]
Polish STANDARd PN-G-15092:1999 - Rockbolts - Tests. Polski Komitet Normalizacy (PKN), Warsaw [in Polish].

Polish STANDARD PN-EN 196-1:2006 - Methods of cement testing - Part 1: Determination of strength. Polski Komitet Normalizacy (PKN), Warsaw [in Polish].

ORTLEPP, W.D., Bornman, J.J., and ERASMus, N. 2001. The Durabar - a yieldable support tendon - design rationale and laboratory results. Proceedings of RaSiM5: Rockbursts and Seismicity in Mines. South African Institute of Mining and Metallurgy, Johannesburg. pp. 263-266.

Patyńska, R. 2014. Rockburst hazard. Annual Report (2013) about the State of Natural and Technical Hazards in Hard Coal Mining. Kabiesz, J. (ed.) Central Mining Institute, Katowice, Poland. pp. 93-102 [in Polish].

Player, J., Villaescusa, E., and Thompson, A. 2008. An examination of dynamic test facilities. Proceedings of the CRC Australian Mining Technology Conference. Lever, P. and Knights, P. (eds.). Australasian Institute of Mining and Metallurgy, Melbourne. pp. 349-379.

Potvin, Y., Hudyma, M., and Jewell, R.J. 2000. Rockburst and seismic activity in underground Australian mines - an introduction to a new research project. Proceedings of GeoEng2000, Lancaster, PA. Technomic Publishers.

Potvin, Y., Wesseloo, J., and HeAl, D. 2010. An interpretation of ground support capacity submitted to dynamic loading. Proceedings of Deep Mining 2010, The Fifth International Seminar on Deep and High Stress Mining, Santiago, Chile, 6-8 October 2010. Van Sint Jan, M. and Potvin, Y. (eds). Australian Centre for Geomechanics, Perth. pp. 251-272.

PRuseK, S. 2008. Methods of gateroads deformation prediction in impact zones of mining with roof caving. Thesis-monograph no, 874. Central Mining Institute, Katowice, Poland [in Polish].

PruseK, S. and Masny, W. 2013. State of the art of the gateroads in Polish coal mining. Mining Report, Glückauf no. 1, February. pp. 28-33.

PruseK, S., MAsny, W., and TuReK, M. 2014. Where we are going - rock bolting in Poland. Proceedings of the 6th Aachen International Mining International Symposium - High Performance Mining. RWTH Aachen. pp. 241-252.

PYTLIK, A. 2005. Yielding rockbolts with high dynamic capacity. Mining Mechanization, vol. 3. Institute of Mining Technology KOMAG [in Polish]

РутLIк, А. 2013a. The tests of yielding rockbolts under a dynamic load of an impact character. Proceedings of Mining and Tunnel Construction 2/2013, Katowice, Poland. pp. 24-30 [in Polish]

PутLIK, A. 2013b. Research on grout and thin-walled shower membrane by use of the box test. Polish Mining Review, no. 12. pp. 126-133. [in Polish]

PYтLIK, A. 2013c. Research on cement and mineral grout type TSM 70, TSM 70F and TSM 70K with high strength and adhesion. Gas Hazards in Hard Coal Mines - Prevention, Fighting, Modeling, Monitoring. Janusza Cygankiewicz, J. and Prusek, S. (eds.). Central Mining Institute. Katowice. pp. 170-181 [in Polish].

РүтLIK, A. 2014. Study based on 'box test' of static load capacity of mining meshes applied with standing support and rockbolting. Polish Mining Review, no. 5. pp. 91-96 [in Polish]

Рүтцік, A. 2015. Dynamic capacity of rockbolts. Occupational Safety and Environmental Protection in Mining, no. 04/2015. pp. 28-35 [in Polish].

Roth, A., CAEA, M., BRÄNdLE, R., and RoREM, E. 2014. Analysis and numerical modeling of dynamic ground support based on instrumented full-scale tests. Proceedins of the 7th International Conference on Deep and High Stress Mining, Sudbury, Canada, 16-18 September. CIM, Montreal. pp. 151-156.

Simser, B., Joughin, W., and OrtLePp, W. 2002. The performance of Brunswick Mine's rockburst support system during a severe seismic episode. Journal of the South African Institute of Mining and Metallurgy, vol. 102. pp. 217-224.

SosnicA, J. 2008. The influence of the construction solution of yielding valves on flexibility of powered support. PhD thesis, University of Science and Technology AGH, Kraków [in Polish].

STEC, K. 2014. Seismic hazard. Annual Report (2013) about the State of Natural and Technical Hazards in Hard Coal Mining. Kabiesz, J. (ed.). Central Mining Institute, Katowice, Poland. pp. 81-92 [in Polish].

Stjern, G. and Myrvang, A. 1998. The influence of blasting on grouted rockbolts. Tunnelling and Underground Space Technology, vol. 13, no. 1. pp. 65-70

TANnANT, D.D, KAISER, P.K., and McDowelL, G.M. 1992. Dynamic support monitoring. Rock Support in Mining and Underground Construction. Kaiser, P.K. and McCreath, D. (eds.). Balkema, Rotterdam. pp. 657-664.

TuReK, M., PruseK, S., and MASNy, W. 2015. Application of mixed support in hard coal mines. Central Mining Institute, Katowice, Poland [in Polish]

WHYATT, J.K. and LOKEN, M.C. 2009. Coal bumps and odd dynamic phenomena a numerical investigation. Proceedings of the 28th International Conference on Ground Control in Mining, Morgantown, WV. pp. $175-180$. 